\title{
THE THREE PILLARS OF THE SOCIAL WORK PROFESSION IN THE UNITED STATES: EDUCATION, PRACTICE AND REGULATION
}

\author{
Jo Ann R. Regan
}

\begin{abstract}
This article will discuss the professionalization of social work in the United States (U.S.). The path to the professional development of social work has been shaped by the features of strong professional associations with external influence on control over education, entrance to the profession through a specific knowledge base and accreditation, codified code of ethics, state licensing, restriction of title, and sanctions for breaches of code of ethics. In the United States, three national social work organizations represent the social work profession in education, practice and regulation. These are referred to as the three pillars of the social work profession with separate missions but shared values to promote the professionalization of social work. These organizations together have influenced social work's progress as a profession in the U.S.
\end{abstract}

\section{Keywords}

social work, social work pillars, social work education, social work regulation, social work practice, principles of social work

\section{Introduction}

Social work has become a global profession practiced in over 144 countries. The global definition of social work is "a practice-based profession and an academic discipline that promotes social change and development, social cohesion, and the empowerment and liberation of people. Principles of social justice, human rights, collective responsibility and respect for diversities are central to social work. Underpinned by theories of social work, social sciences, humanities and indigenous knowledge, social work engages people and structures to address life challenges and enhance wellbeing" (International Association of Schools of Social Work (IASSW), 2014). 
Modern social work has been developing in the U.S. since the 20th century as an independent profession. In the U.S., social work became an occupation in the early 20th century and achieved professional status by the 1920's. The 1930 census classified social work as a profession for the first time. Social work education master's programs have been accredited since the 1950's and baccalaureate programs since 1974 so the accreditation standards have been evolving also in response to economic, social and political conditions of the country. Currently, the racial and social justice issues in the U.S. are having an impact on the revision of standards in terms of how to address anti-racism, diversity, equity and inclusion in the social work curriculum (www. socialworkers.org, 2021).

Like all professions, there has been an interest in the condition of social work as a profession. International systematic comparative studies of the profession have focused on eight key features of the social work profession: (i) public recognition (ii) monopoly over types of work (iii) professional autonomy (iv) knowledge base (v) professional education (vi) social work organizations (vii) ethical standards (Viii) prestige and remuneration. This exploration of the state of the social work profession indicates that certain professional features are common to social work. These are the establishment of professional organizations, the adoption of a professional code of ethics, the development of a specific body of knowledge and the placement of social work training in institutions of higher education. In studies comparing the success of professionalization of social work in different countries, the path to professional development in social work appears to be most shaped by the features of strong professional associations with external influence on state licensing, restriction of title, state sanctions for breaches of code of ethics, control over education and entrance to the profession (Weiss-Gal and Welbourne, 2008). In the United States, three national social work organizations-the Council on Social Work Education (CSWE), the National Association of Social Workers (NASW) and the Association of Social Work Boards (ASWB) represent the social work profession in education, practice and regulation. These are referred to as the three pillars of social work with separate missions but shared values to promote the professionalization of social work. These organizations together have influenced social work's progress as a profession in the U.S.

\section{Social Work Education in the United States}

Specialized professional education in the higher education system is considered to be an essential feature of professions based on the premise that knowledge, values and skills can only be obtained through professional education (Hugman, 1996). In the U.S., control over professional education lies with a non-governmental organization, the Council on Social Work Education (CSWE), that accredits social work education programs. Social work education master's programs have been accredited since the 1950's and baccalaureate programs since 1974. The DSW programs are currently being pilot tested for accreditation. In the U.S., there are four levels of social work education: 
1. BSW - Bachelor's Degree in Social Work

533 accredited; 17 in candidacy

4 year program

Prepares students for generalist social work practice

2. MSW - Master's Degree in Social Work

296 accredited; 31 in candidacy

2-year program (full-time) and 3-4 years program (Part-time)

Required for clinical positions

Prepares students for generalist and a specialized area of practice

3. DSW - Practice Doctorate

Distinct from the PhD

14 programs and growing

4. PhD - Research Doctorate

78 programs

(Council on Social Work Education, 2021)

Only the BSW, MSW and DSW programs are accredited by CSWE. Accreditation is a voluntary, non-governmental process of review that involves a multi-step process that includes preparation \& self-examination, peer review, visit and examination, decision, and a continuous review process. Quality assessment has moved from a model of curriculum design focused on content (what students should be taught) and structure (the format and organization of educational components) to one focused on student learning outcomes. Thus, the competency-based approach focuses on identifying and assessing what students demonstrate in practice. Rather than mandating the academic content that social work programs must provide, the standards now specify nine competencies of professional social work practice that include a set of measurable behaviors. Social work competence is the ability to integrate and apply social work knowledge, values, and skills to practice situations in a purposeful, intentional, and professional manner to promote human and community well-being. The generalist social work competencies include:

- Competency 1: Demonstrate Ethical and Professional Behavior

- Competency 2: Engage Diversity and Difference in Practice

- Competency 3: Advance Human Rights and Social, Economic, and Environmental Justice

- Competency 4: Engage In Practice-informed Research and Research-informed Practice

- Competency 5: Engage in Policy Practice

- Competency 6: Engage with Individuals, Families, Groups, Organizations, and Communities

- Competency 7: Assess Individuals, Families, Groups, Organizations, and Communities

- Competency 8: Intervene with Individuals, Families, Groups, Organizations, and Communities 
- Competency 9: Evaluate Practice with Individuals, Families, Groups, Organizations, and Communities

(Council on Social Work Education, 2015)

Specialized practice competencies are developed for concentrations in a MSW program and should extend and enhance the defined generalist social work competencies listed above. These competencies allow social work to have a unique knowledge base relevant the profession and develop essential research and theory development to support the competencies.

The competency-based approach involves assessing students' ability to demonstrate these competencies and behaviors in practice situations. Through this orientation, programs begin the process of curriculum design with the outcomes, expressed as the competencies and practice behaviors, and then develop the substantive content, pedagogical approach, and educational activities that provide the learning opportunities necessary to develop competence. As in other professional disciplines, the competencybased approach was deemed particularly appropriate for social work since, rather than breadth of knowledge as the indicator of preparation as is the case in certain academic disciplines, competence is the necessary indicator of effective preparation for social work practice (Coe Regan \& Dettlaff, 2016).

The specialized accreditation of social work programs enhances the positioning of social work education in the higher education system but also helps to retain control and influence over what is taught and how it is assessed through the social work competencies adopted by all accredited schools of social work in the U.S. This accreditation function is also related to the regulation function in that social work programs must be accredited by the Council on Social Work Education (CSWE), the sole accreditor of social work programs in the U.S., in order for their graduates to take the social work licensing exam after graduation. Thus, almost all social work programs seek specialized program accreditation through CSWE so graduates of their programs can take the social work licensing exams in all 50 states of the U.S.

\section{Social Work Practice}

The National Association of Social Workers (NASW) was established in the US in 1955 through the consolidation of seven social work organizations. NASW is the professional association for social workers. It is the largest organization of social workers in the United States with 130,000 members, 20,000 student members, 55 Chapters in each state, the District, and territories. It has taken on a number of roles including the development of a code of ethics that was first approved by NASW Delegate Assembly on October 13, 1960 with a latest revision on June 21, 2021 with a focus on self-care and cultural competence. It also disseminates knowledge about social work practice through journals and conferences, and policy advocacy to advance salaries, prestige and working conditions for social workers. All social work students are taught the NASW Code of Ethics in their education and training and must abide by these ethics even as students. 
NASW is a membership organization dedicated to:

- Promoting the quality and effectiveness of social work practice in the United States through services to individuals, groups, and communities

- Furthering the broad objective of improving conditions of life in our democratic society through utilization of the professional knowledge and skills of social work

- Providing opportunity for the social work profession to work in unity toward maintaining and promoting high standards of practice and of preparation for practice and toward alleviating or preventing sources of deprivation, distress, and strain susceptible to being influenced by social work methods and by social action (National Association of Social Workers (NASW), 2021).

The role and functions of NASW mainly promote the interest of members of the profession but also promote the interests of consumers of social work services in a policy activist role. Current and past advocacy issues include medicare reimbursement, student loan forgiveness, social work reinvestment act, and workforce studies. NASW also operates a political action committee (PAC) that endorses and financially contributes to candidates from any party who support NASW's policy agenda.

NASW also does research and data about the social work labor force to determine trends in employment, to address professional training needs, to quantify barriers to quality service delivery, and to inform policy and advocacy efforts. The number of active social workers has been growing steadily. Overall employment of social workers is projected to grow 13 percent from 2019 to 2029 in the U.S., much faster than the average for all occupations. Between 2004/2005 and 2014/2015, the number of practicing social workers grew by $15.5 \%$, according to the Bureau of Labor Statistics (BLS). Among types of social workers, according to the BLS, the most common were child, family, and school social workers $(305,000$ in 2014$)$, followed by health care social workers $(160,000)$; however, health care social workers were the fastest growing group over the decade, with an increase of 45 . Social workers are predominantly female (83\% overall, $85 \%$ of MSW degrees and above); women are likely to continue to dominate the profession, as $86 \%$ of the MSW graduates in 2015 were female (The George Washington University Health Workforce Institute, 2017).

The most common type of employer for social workers is a private, nonprofit, or charitable organization (34.3\% of all social workers); however, $41 \%$ of social workers work for the government when combining federal, state and local governments. Private, for-profit companies and businesses employ $22.3 \%$ of social workers, leaving just $2.5 \%$ self employed or working in a family business. In terms of the settings, the greatest concentration of social workers is found in individual and family services (36.6\%), followed by $11.4 \%$ in administration of human resource programs, $10.6 \%$ in hospitals, and $8.3 \%$ in outpatient care centers (The George Washington University Health Workforce Institute, 2017). 


\section{Social Work Regulation}

The Association of Social Work Boards (ASWB) is another national association in the U.S. that promotes the professional regulation of social work practice. The mission of ASWB is to strengthen protection of the public by:

- Providing support and services to the social work regulatory community

- To advance safe, competent, and ethical practices (Association of Social Work Boards, 2021)

The support and services to enhance the profession include protecting the title of social worker, protecting the practice of social work, recognizing social work as an important profession, facilitating reimbursement and increasing public awareness. It also focuses on protection of the public from incompetent, unsafe, unethical social workers, providing recourse for client if harmed by licensed social worker, guarantees privileged communication for client and establishes minimum qualifications to enter/remain in profession. Resources to provide these support and services include the ASWB Examinations Program that provides licensing exams in all 50 states and its territories, a Public Protection Database, Model Social Work Practice Act.

Model Regulatory Standards for Technology and Social Work Practice, ACE (Approved Continuing Education) program, a Path to Licensure campaign and Social Work Registry. All of these services are done in conjunction with CSWE and NASW.

There are over 500,000 licensed social workers in the U.S. Social workers are licensed at the clinical level in all 50 states and its territories, the MSW level in 46 states and the BSW level in 40 states. Forty-five states include both title protection and scope of practice for social work practice. Title protection ensures that only persons that hold the minimum qualifications can call themselves a social worker. Scope of practice describes the services that a qualified professional is deemed competent to perform, and permitted to undertake in keeping with the terms of their professional license.

\section{Discussion}

This exploration of the state of the social work profession as it is reflected in education, practice and regulation indicates that social work in the U.S. has developed several key professional features. These features are related to the establishment of three national organizations that work together to advocate for the profession in terms of education, practice and regulation. CSWE, the education association, ensures the development and dissemination of a specific body of knowledge for social work and the specialized accreditation of social work programs in higher education. It also sets the minimum competence a social work professional must have in order to enter the profession. NASW, the practice association, ensures that a single, formal, nationwide code of ethics reflects the values and priorities of social work practice. Also, they develop the profession 
further through revisions to the code of ethics, journals, training and conferences. ASWB, the regulation association, works to ensure enforceable licensing regulations, restrictions on the use of title of social worker, sanctions for code of ethics violations and scope of practice guidelines. Weiss-Gal and Welbourne (2008) found that the ability of social workers to establish national organizations focused on these areas are examples of "inner power," where social workers work cooperatively as a professional entity and exert influence on the body of social workers as a professional group. They conclude that most professional features achieved for social work are primarily due to this "inner power". The ability of social workers to create a unique knowledge base, establish a code of ethics and sanctions for violating code of ethics reflect this type of power.

\section{Conclusion}

Social work's progress as a profession in the U.S. has been shaped by the interaction of these three national social work organizations, who act as pillars of the profession, as they work together to achieve certain defined professional aims. They have maintained a level of cohesiveness to exert internal professional power to influence the profession and promote the interests of those who call themselves social workers especially amid changing political, economic and social changes. The aspiration to professional status is strong and acts as a guiding force for these professional organizations as they continue to promote the profession of social work.

\section{References}

Association of Social Work Boards (2021). Association of Social Work Boards. Retrieved from https://www.aswb.org/.

Coe Regan, J. R., \& Dettlaff, A. J. (2016). Understanding and assessing competence: Challenges associated with the competency-based approach to social work education. In I. Taylor, M. Bogo, M. Lefevre, \& B. Teater (Eds.), Routledge international handbook of social work education (27-37). New York, NY: Routledge International.

Council on Social Work Education. (2015). Educational policy and accreditation standards. Retrieved from https://www.cswe.org/getattachment/Accreditation/Standards-andPolicies/2015-EPAS/2015EPASandGlossary.pdf.aspx

Council on Social Work Education (CSWE). (2021). Current Number of Social Work Programs. Retrieved from https://www.cswe.org/Accreditation

Hugman, R. (1996). Professionalization in social work: the challenge of diversity. International Social Work, 39, 131-147. 
International Association of Schools of Social Work (IASSW). (2014). Global definition of social work. Retrieved from https://www.iassw-aiets.org/global-definition-of-socialwork-review-of-the-global-definition/

National Association of Social Workers (NASW). (2021). About. Retrieved from https:// www.socialworkers.org/About

The George Washington University Health Workforce Institute. (2017). Profile of the Social Work Workforce. Retrieved from https://www.cswe.org/Centers-Initiatives/Initiatives/ National-Workforce-Initiative/SW-Workforce-Book-FINAL-11-08-2017.aspx

Weiss-Gal, I. \& Welbourne, P. (2008). The professionalisation of social work: a crossnational exploration. International Journal of Social Welfare, 17, 281-290.

\section{Author}

Jo Ann R. Regan

The Catholic University of America National Catholic School of Social Service Washington, D.C., USA

reganj@cua.edu 